\title{
Effect of Free Fatty Acids and Amino Acids on Glucagon and Insulin Secretions in Normal and Diabetic Ducks
}

\author{
F. Laurent and P. Mialhe \\ Laboratoire de Physiologie Générale, Strasbourg, France
}

\begin{abstract}
Summary. The relationship between two metabolites, free fatty acids (FFA) and amino acids (AA), and the two main pancreatic hormones, insulin and glucagon, was studied by infusing small amounts of these metabolites into normal and diabetic Peking ducks, i. e. two days after subtotal pancreatectomy.

Infusion of oleic acid $(0.365 \mathrm{~g} / \mathrm{kg} / 30 \mathrm{~min}$ as an emulsion in plasma) indicated a suppressive effect of free fatty acids on glucagon secretion, but was without effect on insulin secretion, in normal as well as in diabetic ducks, indicating that insulin might not be directly involved in the FFA-glucagon feedback in the duck.

Infusions of arginine for one hour $(1 \mathrm{~g} / \mathrm{kg} / \mathrm{h})$ into normal ducks, hyperglycaemic normal birds (as a result of glucose infusion: $1 \mathrm{~g} / \mathrm{kg} / \mathrm{h}$ ) and diabetic ducks, suggested the persistence of an amino acid effect on glucagon secretion, and a slight reduction of the effect on insulin secretion in diabetes. This suggests that insulin may not be involved in amino acidinduced glucagon secretion in the duck.
\end{abstract}

Key words: Duck, feedback mechanism, glucagon, insulin, free fatty acids, amino acids, glucose, diabetes, pancreatectomy.

The present investigation was undertaken to study the relationship of free fatty acids (FFA) and amino acids (AA) with insulin and glucagon in normal and diabetic ducks and to see if insulin is a prerequisite for the functioning of normal feedback mechanisms, as it is for the glucose-glucagon interplay [22].

An effect of FFA on glucagon secretion has been observed in normal man [10] and the dog [24, 25], but the response of glucagon to an experimental increase of FFA in diabetes has never been studied in mammals. This study was nevertheless undertaken under physiological conditions in the duck, a species in which a transient diabetes can be induced by subtotal pancreatectomy $[27,22]$ and where glucagon seems to be of particular importance $[27,28,29]$ especially in regulation of lipid metabolism [3, 30].

Likewise, amino acid-induced glucagon secretion has been observed in normal man [1,31], in the dog [33], and in the normal and hypophysectomised duck $[6,35]$. The study of the secretion of insulin and glucagon during hyperaminoacidaemia in normal and diabetic ducks, seemed to be of interest, given that glucagon plays an important rôle in substrate regulation in birds $[27,28,29]$.

\section{Material and Methods}

\section{Animals}

Male Peking ducks were used in our experiments. They were kept indoors in individual cages between the operation and the test, and maintained on a normal diet with fowl pellets ("Grands Moulins de Paris", Nancy, France) and tap water ad libitum.

\section{Subtotal Pancreatectomy}

This was performed under local anaesthesia, on $16-20 \mathrm{~h}$ fasted ducks [27]. Only the anterior part of the splenic lobe was left.

\section{Infusions and Blood Sampling}

The ducks were tied to a board, lying on their backs, and they remained immobile under these conditions: no anaesthesia was needed. Infusions were performed on $16-20 \mathrm{~h}$ fasted ducks, through a polyethylene catheter inserted into a wing or a leg vein.

1. Free Fatty Acid Infusions. The animals were infused with oleic acid $(0.365 \mathrm{~g} / \mathrm{kg} / 30 \mathrm{~min})$, emulsified in their own plasma drawn at 


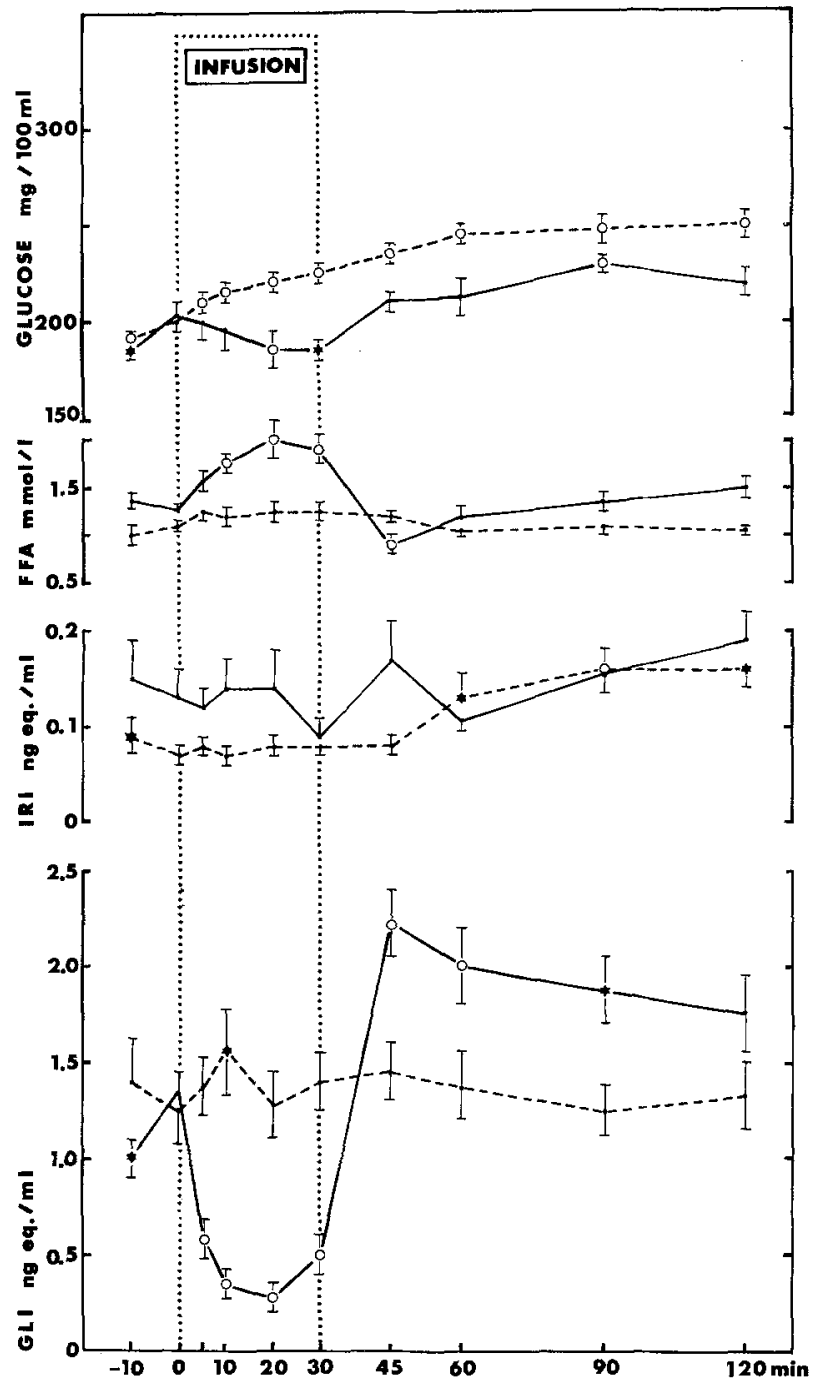

Fig. 1. Effect of an infusion of oleic acid $(0.365 \mathrm{~g} / \mathrm{kg} / 30 \mathrm{~min})$ in normal fasted duck plasma, in 11 ducks (-) and of a 30 min infusion of normal fasted duck plasma in 10 ducks (--), on plasma glucose, free fatty acids, IRI and GLI. In this figure, as in the following ones, vertical bars represent $\pm \mathrm{SEM}$; $O$ and $\star$ respectively correspond to highly significant $(p<0.01)$ and significant $(p<0.05)$ differences from the zero time value

least one month before [13]. Control animals were infused with their own plasma, under the same conditions.

2. Amino Acid Infusions. Arginine was infused at $1 \mathrm{~g} / \mathrm{kg} / \mathrm{h}$, diluted with $\mathrm{NaCl}(9 \mathrm{~g} / 1)$.

3. Glucose Infusions. Glucose was infused at a rate $(1 \mathrm{~g} / \mathrm{kg} / \mathrm{h})$ which imitated the hyperglycaemia occuring in diabetes.

4. Saline Infusions. $\mathrm{NaCl}(9 \mathrm{~g} / \mathrm{l})$ was infused during some control experiments.

Blood samples, drawn by a second catheter inserted into a wing vein, were kept on ice until centrifugation, and plasma was then frozen at $-20^{\circ} \mathrm{C}$ until use. Trasylol has been shown to be unnecessary for preventing degradation of glucagon in duck plasma [23]. Storage time ranged between one month and two years.

\section{Plasma Determinations}

1. Plasma glucose was measured with a Technicon Autoanalyzer after dialysis, using a ferricyanide reagent [15].

2. Plasma free fatty acids were measured spectrophotometrically [21].

3. Plasma amino acids. Plasma amino nitrogen was determined on deproteinised plasma, by a ninhydrin method with a Technicon Autoanalyzer [35]. Plasma arginine was measured after chromatography on deproteinised plasma, with a Unichrom Beckman Autoanalyzer.

4. Plasma immunoreactive insulin (IRI) was determined by radioimmunoassay, using a dextran-coated charcoal method of separation (8) and beef insulin as a standard. At the concentrations used, beef and duck insulin crossreact in a similar way with our antibody [22]. The results are expressed as ng beef IRI equivalents $/ \mathrm{ml}$ plasma.

5. Glucagon like immunoreactivity (GLI) was determined by the radioimmunoassay of Leclercq-Meyer et al. [23], using a dextrancoated charcoal method of separation. Trasylol has been shown to be unnecessary in our method of glucagon determination [7]. The results, read from a standard curve using porcine glucagon are therefore given as ngEq of pig glucagon. Serial dilutions of avian pancreatic extracts compete with our antibody like pork glucagon [17]. The sensitivity of the assay is $0.1 \mathrm{ng} / \mathrm{ml}$. The SEM ranges between 0.009 and 0.13 for plasma concentrations between 0 and $2 \mathrm{ng} / \mathrm{ml}[14]$

The 7/69 antibody used in this assay, at a dilution of 1200 is not specific for pancreatic glucagon, but the so-called "nonspecific antibodies" are precisely the ones able to react fully with duck glucagon [15]. We can nevertheless assert, from the following observations, that the variations mentioned correspond to pancreatic glucagon (IRG):

- No change in plasma GLI is observed in fasted, totally depancreatised ducks given glucose [36], or infused with oleic acid [13].

- There is no significant alteration of GLI in the same animals during the first hour of arginine infusion, even at higher rates [35]; after $60 \mathrm{~min}$ a small, delayed rise in gut GLI occurs.

Since we did not study variations occurring after one hour of infusion, we can confidently assert that the GLI alterations reported here are exclusively of pancreatic origin.

6. Calculations and statistical methods. Variations in the secretion of glucagon and insulin were calculated from areas under the curves, and reported as $\mathrm{ngEq} / \mathrm{ml} \times \min$. Student's " $\mathrm{t}$ " test was used to compare mean values which are given \pm SEM.

\section{Results}

\section{Effect of FFA on Glucagon and Insulin Secretions in Normal and Diabetic Ducks}

\section{1) Normal Ducks (Fig. 1)}

a. Controls. In order to assess further the effects of changes in plasma FFA levels on pancreatic cells, 30 minutes infusions of plasma without oleic acid were performed into 10 normal fasted ducks.

No change in plasma FFA occurred during or 


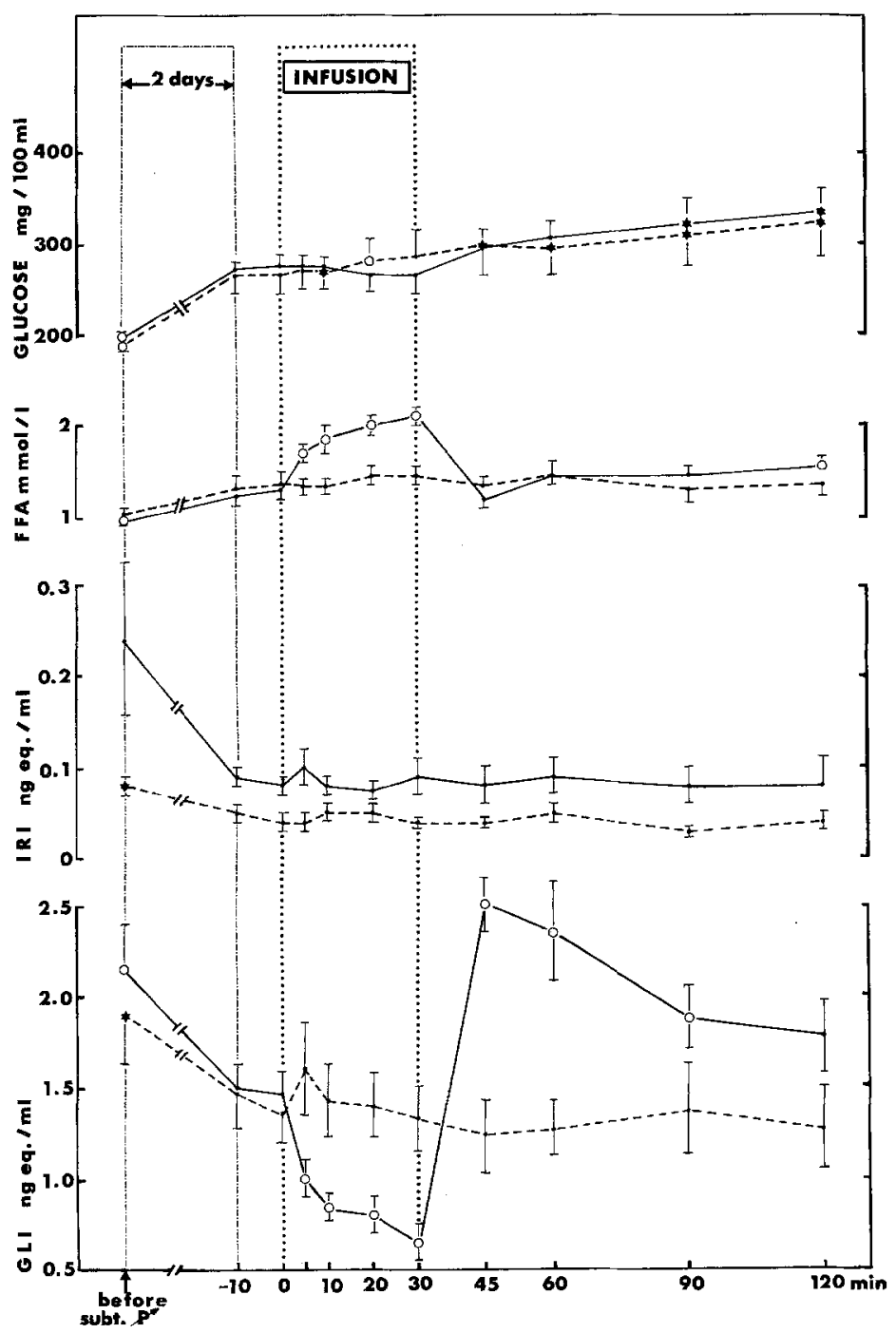

Fig. 2. Effect of an infusion of oleic acid $(0.365 \mathrm{~g} / \mathrm{kg} /$ $30 \mathrm{~min}$ ) in normal fasted duck plasma (-), in 11 diabetic ducks, two days after subtotal pancreatectomy (subt. $P^{*}$ ) and of a 30 min infusion of normal fasted duck plasma (---) in 9 subtotally depancreatised ducks for two days, on plasma glucose, free fatty acids, IRI and GLI.I, $\circ, \star$,: same symbols as in Figure 1 after plasma infusion. Plasma glucose slowly increased during the experiment. There was no change in plasma IRI level during the infusion, but a significant increase was observed during the second hour of the test, probably in response to the developing hyperglycaemia. No change in GLI concentration occurred, except for an unexplained rise at 10 minutes.

b. Oleate Infusion. Mean plasma FFA increased significantly from $1.28 \mathrm{mmol} / 1$ to a peak value of $2 \mathrm{mmol} / \mathrm{l}$ at 20 minutes with oleic acid infusion in normal ducks $(\mathrm{n}=11)$. A significant drop of plasma glucose occured at 20 minutes $(p<0.01)$. Plasma IRI did not vary either during the infusion or thereafter. A prompt and significant GLI decline was observed as early as 5 minutes $(\mathrm{p}<0.001)$, with a nadir at 20 minutes $(p<0.001)$. The mean area of glucagon decrement averaged $25 \pm 3 \mathrm{ngEq} / \mathrm{ml} \times$ min. Mean GLI level significantly increased after the infusion, the values returning to normal two hours after the beginning of the experiment.

\section{2) Diabetic Ducks (Fig. 2)}

Two days after subtotal pancreatectomy, we noticed an increase in plasma glucose and FFA, and a decrease in plasma IRI and GLI, in both control and oleate infused animals.

a. Controls. No change in plasma FFA, IRI, or GLI levels occurred during plasma infusion into diabetic ducks $(\mathrm{n}=9)$; nevertheless, plasma glucose progressively but significantly increased during the whole experiment.

b. Oleate Infusions. A significant increase in plasma FFA occurred in diabetic ducks $(\mathbf{n}=11)$ during the oleate infusion ( $p<0.01$ from 5 to $30 \mathrm{~min}$ ). Mean 


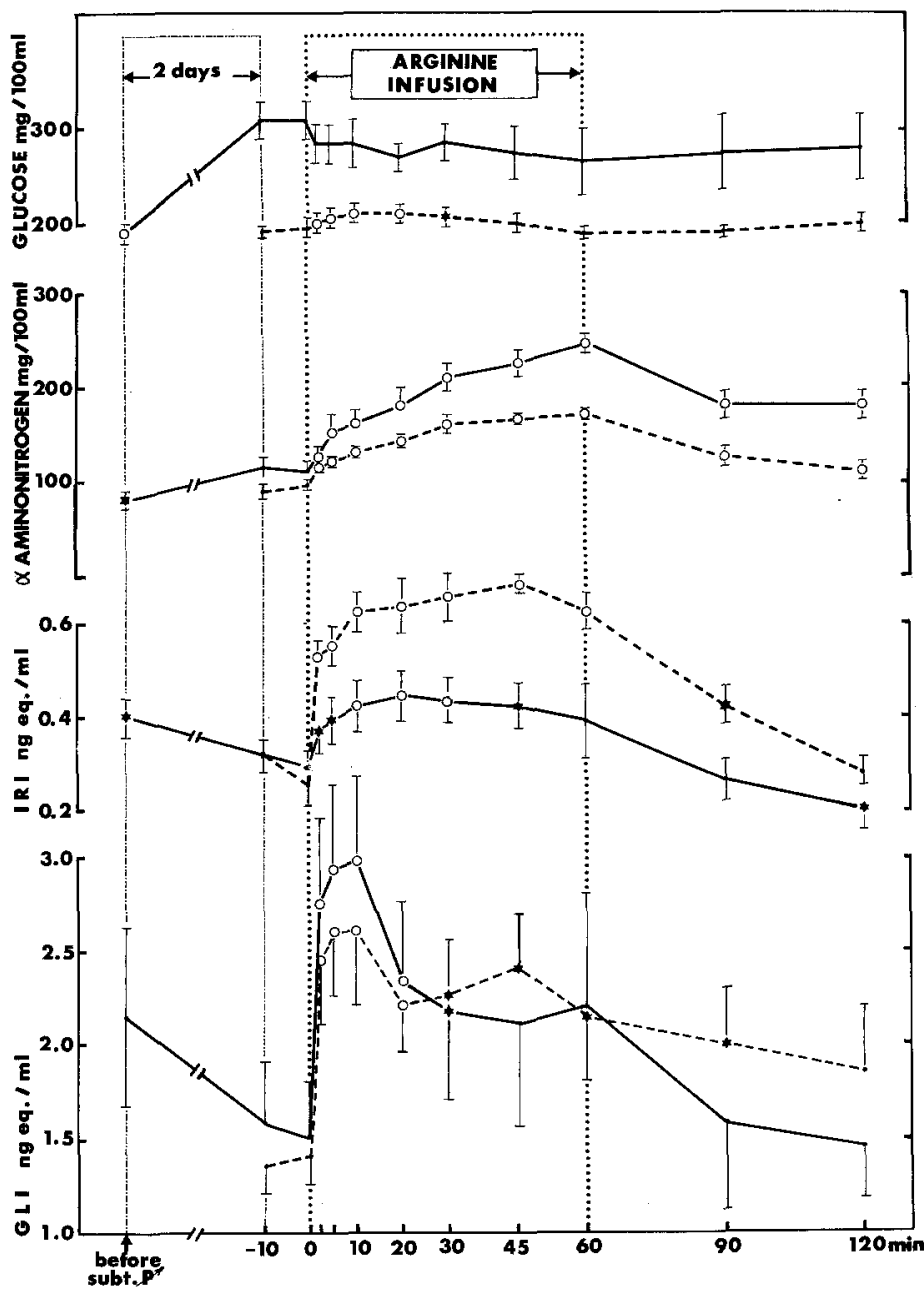

Fig. 3. Effect of an infusion of arginine $(1 \mathrm{~g} / \mathrm{kg} / \mathrm{h})$ in 8 normal ducks (--) and in 9 diabetic ducks (-), two days after subtotal pancreatectomy (Subt. $P^{\prime \prime}$ ), on plasma glucose, $\alpha$ amino nitrogen, IRI and GLI.I, $\circ, \star$,: same symbols as in Figure 1 plasma glucose showed a slight but non-significant decrease during the infusion, followed by a significant increase at the end of the experiment. As in normal ducks, the oleate administration induced no change in plasma IRI. Although less important than in normal animals $(\mathrm{p}<0.05$; the mean area of glucagon decrement averaged $17 \pm 2 \mathrm{ngEq} / \mathrm{ml} \times \min$ in diabetic ducks instead of $25 \pm 3$ in normal animals), the drop in plasma GLI which occurred during the oleate infusion in diabetic animals was prompt and sustained ( $p<0.001$ from 5 to 30 minutes). As in normal animals, plasma GLI significantly increased after the infusion.

Thus, in diabetic animals as in normal ones, an elevation in plasma FFA was associated with a suppression of glucagon secretion, but was without effect on the insulin response.

\section{Effect of Amino Acids on Glucagon and Insulin Secretion in Normal and Diabetic Ducks}

\section{1) Normal Fasted Ducks (Fig. 3)}

Arginine was infused at a constant rate of $1 \mathrm{~g} / \mathrm{kg} / \mathrm{h}$, for one hour, in 8 normal fasted ducks. Plasma glu- cose rose significantly ( $p<0.01$ from 2 to 20 minutes; $p<0.05$ at 30 minutes) at the beginning of the infusion, returning to basal values thereafter. Plasma $\alpha$ amino-nitrogen increased significantly ( $p<0.01$ ) from $94 \mathrm{mg} / 100 \mathrm{ml}$ to a peak value of $171 \mathrm{mg} / 100 \mathrm{ml}$ at 60 minutes, and plasma arginine levels rose from 25 to $463 \mu \mathrm{mol} / 100 \mathrm{ml}(\mathrm{p}<0.001)$ at the end of the infusion.

A significant $(p<0.01)$ rise in IRI already occurred by 2 minutes, the values remaining above control levels $(p<0.01)$ for the rest of the 60 minutes period, then returning to basal levels two hours after the start of the infusion. A significant $(\mathrm{p}<0.01$ from 2 to 20 minutes, $p<0.05$ from 30 to 90 minutes) rise in plasma GLI concentration was observed throughout the infusion.

\section{2) Diabetic Ducks (Fig. 3)}

Nine diabetic ducks were infused with arginine $(1 \mathrm{~g} /$ $\mathrm{kg} / \mathrm{h}$ ) two days after surgery. No change in plasma glucose was found. Basal plasma $\alpha$ amino nitrogen concentration rose significantly $(\mathrm{p}<0.05)$ in diabetic ducks $(113 \mathrm{mg} / 100 \mathrm{ml})$ compared with the same ani- 


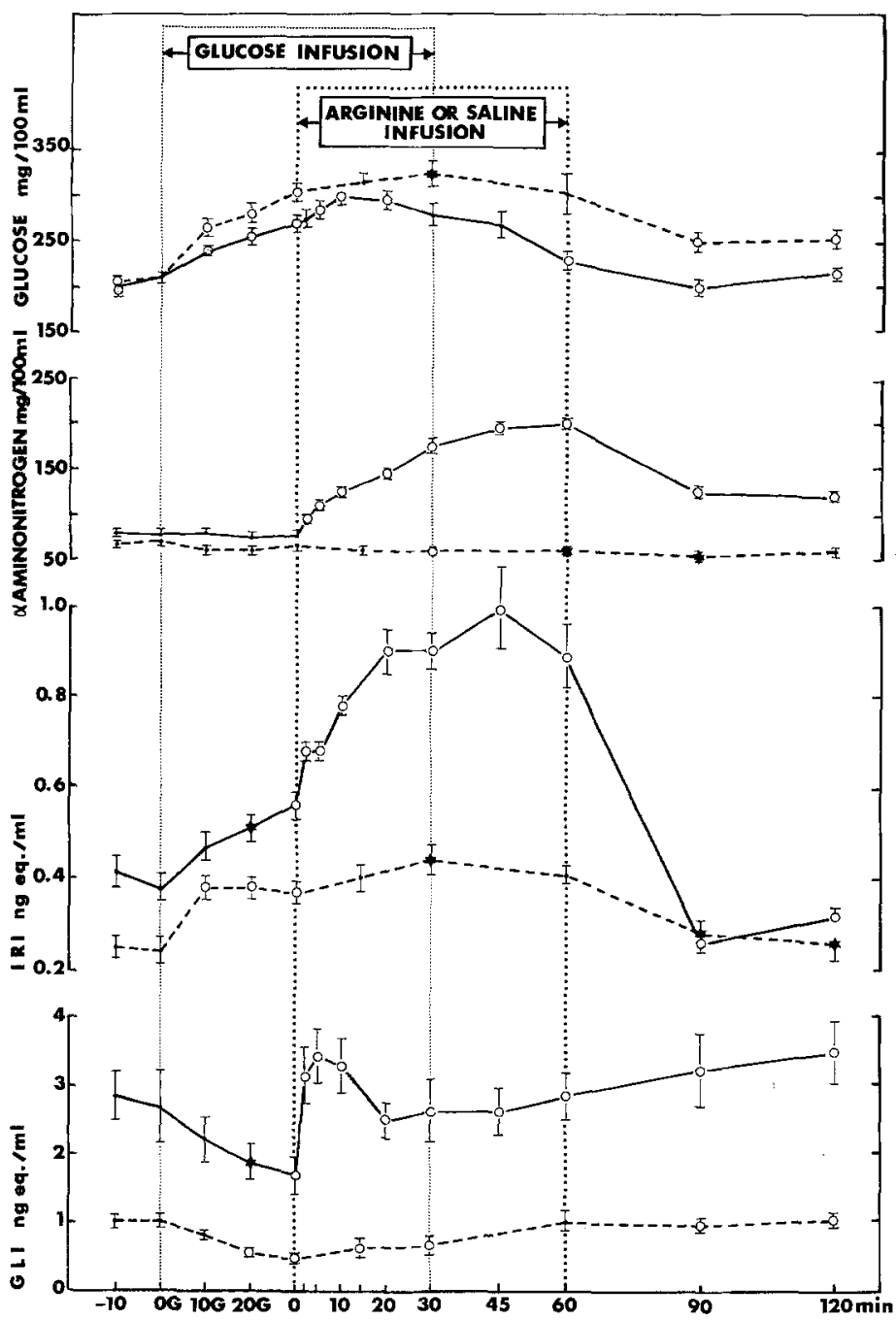

Fig. 4. Effect of an infusion of arginine $(1 \mathrm{~g} / \mathrm{kg} / \mathrm{h})(-)$ or $\mathrm{NaCl}(9 \mathrm{~g} / \mathrm{l})(--)$ for one hour, in ducks rendered hyperglycaemic by a one-hour glucose infusion $(1 \mathrm{~g} / \mathrm{kg} / \mathrm{h})$, starting $30 \mathrm{~min}$ before the beginning of the arginine or saline, on plasma glucose, $\alpha$-amino nitrogen, IRI and GLI.I, 0 , ,; same symbols as in Figure 1. (The values $-10,10 \mathrm{G}, 20 \mathrm{G}$ and 0 min were compared to the value $0 \mathrm{G}$, which corresponds to the beginning of the glucose infusion, and the values $2 \mathrm{~min}$ to $120 \mathrm{~min}$ were compared to $0 \mathrm{~min}$, i. e. the beginning of the arginine or saline infusion) mals before surgery $(76 \mathrm{mg} / 100 \mathrm{ml})$. The arginine infusion elicited a significant rise $(\mathrm{p}<0.01$ from 0 to 120 minutes) in plasma $\alpha$ amino nitrogen concentration from $113 \mathrm{mg} / 100 \mathrm{ml}$ to a peak value of $244 \mathrm{mg} /$ $100 \mathrm{ml}$ at 60 minutes; plasma arginine abruptly rose ( $p<0.001$ ), from 20 to $770 \mu \mathrm{mol} / 100 \mathrm{ml}$ at the end of the infusion.

Although the mean area of insulin increment was significantly lower $(p<0.001)$ in diabetic animals $(8$ $\pm 2 \mathrm{ngEq} / \mathrm{ml} \times \mathrm{min}$ ), compared with normal ones $(22 \pm 2 \mathrm{ngEq} / \mathrm{ml} \times \mathrm{min})$, the rise in plasma IRI induced by arginine was prompt and significant ( $p<0.05$ at 2, 5, 45 minutes, and $p<0.01$ from 10 to 45 minutes), but less marked and not sustained. The diabetic ducks given arginine exhibited an acute rise in plasma GLI $(p<0.01$ from 2 to 20 minutes, $p<0.05$ at 30 minutes). The area of glucagon increment averaged $52 \pm 16 \mathrm{ngEq} / \mathrm{ml} \times \min$ in these diabetic animals, which was not significantly different from the normal response $(56 \pm 12 \mathrm{ngEq} / \mathrm{ml} \times \mathrm{min})$.

Thus, in spite of lower basal insulin levels and responses, an arginine infusion in diabetic ducks induced an almost normal glucagon rise in plasma.

\section{3) Normal Hyperglycaemic Ducks (Fig. 4)}

In order to reproduce the hyperglycaemia occurring with diabetes, glucose was infused at a rate of $1 \mathrm{~g} / \mathrm{kg} /$ $\mathrm{h}$, for one hour into 8 normal fasted ducks. Arginine was infused at the same rate as before $(1 \mathrm{~g} / \mathrm{kg} / \mathrm{h})$, for one hour, the infusion starting $30 \mathrm{~min}$ after the beginning of the glucose administration.

In this case, mean plasma glucose concentration increased significantly from 210 to $304 \mathrm{mg} / 100 \mathrm{ml}$ at the start of the arginine infusion, and reached $322 \mathrm{mg} / 100 \mathrm{ml} 30$ minutes later, i. e. at the end of the glucose infusion. No change in plasma amino nitrogen level was observed during the first thirty minutes of the glucose infusion. There was a prompt increase $(\mathrm{p}<0.01)$ immediately after the beginning of arginine administration. Plasma IRI progressively 

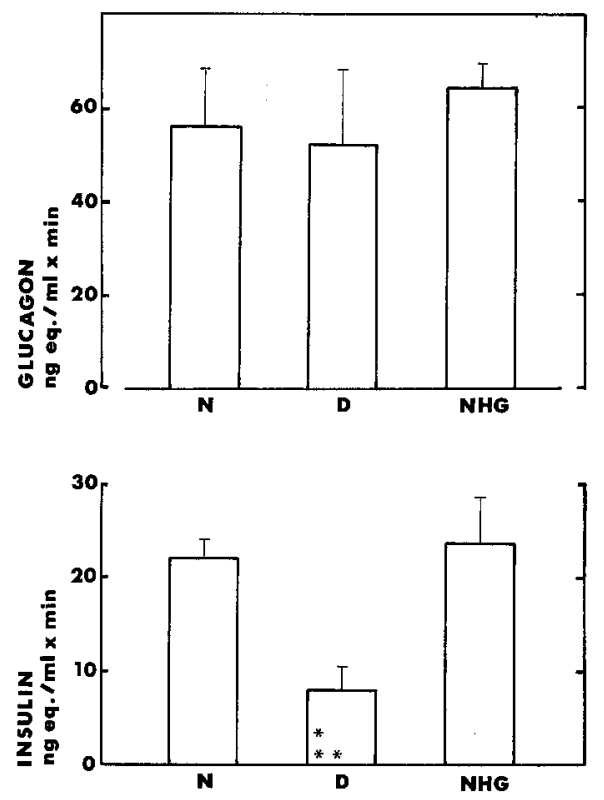

Fig. 5. Areas of glucagon and insulin increment, during a one-hour infusion of arginine, in 8 normal (N), 9 diabetic (D) and 8 normal hyperglycaemic (NHG) ducks. * indicates a significant difference $(\mathrm{p}<0.001)$ compared with $\mathrm{N}$, and $* *$ a significant difference $(\mathrm{p}<0.01)$ compared with NHG

increased $(p<0.05$ at 20 minutes, $p<0.01$ at 30 minutes) until the thirtieth minute of glucose infusion, followed by an abrupt rise as soon as the arginine infusion was started ( $\mathrm{p}<0.01$ from 2 to 60 minutes). The area of insulin increment during the arginine infusion in hyperglycaemic ducks averaged $24 \pm 5 \mathrm{ngEq} / \mathrm{ml} \times \mathrm{min}$, which was not significantly different from the normal fasting value $(22 \pm$ $2 \mathrm{ngEq} / \mathrm{ml} \times \mathrm{min}$ ) but significantly higher than the diabetic value $(8 \pm 2 \mathrm{ngEq} / \mathrm{ml} \times \mathrm{min})$. Plasma GLI concentration slowly decreased $(p<0.05$ at 20 minutes, $\mathrm{p}<0.01$ at 30 minutes) during the first half of glucose infusion. As soon as the arginine infusion started, plasma GLI level sharply increased $(p<0.01$ from 2 to $120 \mathrm{~min}$ ). The area of glucagon increment in hyperglycaemic ducks averaged $64 \pm 5 \mathrm{ngEq} / \mathrm{ml}$ $\times$ min and was not significantly different from nor$\mathrm{mal}(56 \pm 12)$ and diabetic values $(52 \pm 16 \mathrm{ngEq} / \mathrm{ml}$ $\times \min )$.

4) Normal Hyperglycaemic Ducks With Saline Infusion (Fig. 4)

Glucose was infused at a rate of $1 \mathrm{~g} / \mathrm{kg} / \mathrm{h}$ for one hour. Saline instead of arginine, was infused for one hour, the infusion starting, as before, $30 \mathrm{~min}$ after the beginning of the glucose infusion.

In this case, plasma glucose significantly increased $(\mathrm{p}<0.01)$ from 210 to an average of
$322 \mathrm{mg} / 100 \mathrm{ml}$ at the end of the glucose infusion, and decreased thereafter. Plasma IRI significantly increased during the beginning of the glucose infusion $(p<0.01)$ but the area of insulin increment from 0 to 60 minutes (which corresponds to the whole period of saline infusion and to 30 minutes of the glucose infusion), averaged $2.5 \pm 0.6 \mathrm{ngEq} / \mathrm{ml} \times$ min and was much reduced $(p<0.001)$ compared with hyperglycaemic animals given arginine $(24 \pm$ $5 \mathrm{ngEq} / \mathrm{ml} \times \mathrm{min})$. Plasma GLI significantly decreased ( $\mathrm{p}<0.01$ from 20 to 30 minutes) during the glucose infusion. The area of glucagon increment from 0 to 60 minutes averaged $3.5 \pm 3.8 \mathrm{ngEq} / \mathrm{ml} \times$ min, and was significantly lower $(p<0.05)$ than in hyperglycaemic animals given arginine: $64 \pm$ $5 \mathrm{ngEq} / \mathrm{ml} \times \mathrm{min}$.

\section{Discussion}

\section{Free Fatty Acids Interplay with Insulin and Glucagon}

The plasma GLI alterations mentioned in our experiments correspond to pancreatic glucagon, since no GLI change occurred in totally depancreatised ducks given the same FFA infusions [13].

1) FFA and Insulin Secretion. In normal ducks, small alterations in plasma FFA within a physiological range, induce no change in insulin secretion. A FFAinsulin interplay does not seem to exist in the normal duck. In contrast to this are the results for the dog [25] and for man [2]. In the former case, plasma FFA alterations have been reported to change insulin secretion, and in the latter, arguments for the role played by plasma FFA in the control of insulin secretion have been put forward.

In diabetic ducks, as is the case in normal animals, a physiological increase in plasma FFA induces no change in insulin secretion.

There is thus no evidence of the existence of a FFA-insulin interplay either in the normal or in the diabetic duck.

These results bear out the absence of any antilipolytic role of insulin in the bird $[3,12,20]$ and the only antilipolytic factor up till now demonstrated in the duck is gut GLI [19].

2) FFA and Glucagon Secretion. Glucagon is a potent lipolytic hormone, especially in chickens [18] and ducklings [19], in which the normal peripheral levels of glucagon of pancreatic origin $(500$ and $1000 \mathrm{pg} / \mathrm{ml}$ respectively) induce a near maximal lipolysis.

Conversely, in normal ducks, a physiological al- 
teration in plasma FFA induces a change in glucagon secretion, as already reported by Gross et al. [13], and confirmed here. The existence of a similar FFAglucagon interplay has been previously reported in normal man [10] and in the dog [24, 25].

On the other hand, in diabetic ducks, i. e. two days after subtotal pancreatectomy, the glucoseglucagon interplay is abolished, and can be restored by insulin therapy [22], but a physiological increase in plasma FFA still induces a decrease in the alpha cell secretion. The suppressive effect of FFA on glucagon secretion nevertheless seems to be slightly reduced during diabetes. Similarly, in hypophysectomised ducks, where basal insulin secretion is very low, small alterations in plasma FFA within a physiological range [6] still induce a decrease in plasma glucagon.

Since in the presence of a very small basal concentration of insulin, the FFA-induced glucagon suppression remains effective, insulin might not be necessary in this interplay. This might indicate the existence of a direct effect of FFA on the alpha cell.

\section{Amino Acid Interplay with Insulin and Glucagon}

Since no alteration in gut GLI could be observed during the first hour of arginine infusion in totally depancreatised ducks given even higher amounts of arginine [35], it may therefore be assumed that the GLI alterations here mentioned are of pancreatic origin.

1) Normal State. An arginine infusion, resulting in a two-fold increase in plasma alpha amino nitrogen due to a twenty-fold rise in arginine, induces an acute increase in glucagon and insulin secretions, together with a slight hyperglycaemia.

These data suggest the existence of an arginineglucagon and an arginine-insulin interplay in normal fasted ducks, as already reported at supraphysiological levels in normal [35] and hypophysectomised ducks [6], in normal man $[1,4,31]$ and in the dog [33].

2) Diabetes. The basal hyperaminoacidaemia observed in diabetic ducks could be ascribed to a lowering of basal insulin and glucagon secretions since insulin is known to inhibit the peripheral release and glucagon to stimulate the hepatic uptake of amino acids [26].

A two-fold increase in plasma alpha amino nitrogen, mainly due to arginine, induced a normal glucagon increase, but a reduced insulin response (Fig. 5), in diabetic ducks, suggesting the persistence of normal arginine-induced glucagon secretion during dia- betes, despite lowered basal insulin secretion and a decreased insulin response.

Contrasting with its key role in the effectiveness of the glucose-glucagon interplay in the duck [22], insulin may thus not be involved in amino acidinduced glucagon secretion in this species (Fig. 6).

A similar persistence in the glucagon response to hyperaminoacidaemia $[31,39]$, with even increased secretion, concomitant with a reduced $[4,5]$ or abolished [37] insulin response, occurs in diabetic man.

3) Effect of Hyperglycaemia. In normal ducks rendered hyperglycaemic to an extent comparable with diabetes, augmentation in plasma arginine induces a rise in glucagon and insulin secretion similar to that occurring in normoglycaemic animals (Fig. 5). Glycaemia does not thus seem to alter the response of alpha or beta cells to arginine (Fig. 6).

In sharp contrast are the results obtained in mammals, where combined hyperaminoacidaemia and hyperglycaemia result in an increase in insulin and an abolished glucagon response $[9,34,38]$. This bi-hormonal situation would favour protein synthesis at the expense of gluconeogenesis [32].

4) Roles and Action of Arginine on Glucagon and Insulin Secretion. Neither glucose, nor insulin, nor pituitary hormones [6] seem to affect aminogenic glucagon secretion in the duck. We therefore suggest a direct and constant action of arginine on the alpha cell, the primary response of the duck pancreas to this amino acid being a secretion of glucagon, and gluconeogenesis.

Moreover, arginine seems to be a more potent stimulus of the alpha cell than glucose in the duck, since concomitant hyperaminoacidaemia and hyperglycaemia elicit a rise in glucagon secretion.

Conflicting results have been reported in the isolated perfused rat pancreas, where it has been postulated that the binding of glucose to alpha cell
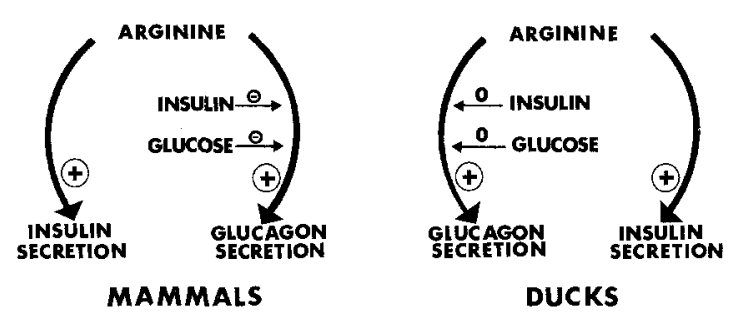

Fig. 6. Arginine-induced glucagon secretion as influenced by insulin and glucose, and arginine-induced insulin secretion in mammals and ducks. Insulin or glucose inhibit the amino acid-induced glucagon response in mammals, but are without effect on it in the duck. In both cases, arginine stimulates insulin secretion. $\oplus$ indicates a stimulatory effect, $\ominus$ an inhibitory effect and 0 the absence of an effect 
glucoreceptors (34) has a permissive inhibitory effect on the aminogenic glucagon response. Furthermore, in man (11), insulin has been ascribed a direct action on the response of the alpha cell to arginine.

Although its influence on the arginine-induced glucagon secretion might be insignificant in the duck, aminogenic insulin secretion probably favours protein synthesis, and might perhaps play a role in glucoregulation, i. e. prevention of hyperglycaemia provoked by an unchanged aminogenic glucagon secretory response, whatever the glycaemic pattern may be.

Acknowledgements. The authors wish to thank Pr. Y. Boulanger for arginine determinations, Miss M. Horrenberger, Mrs. M. Roth and G. Sommermeyer for their valuable technical assistance and Miss M. Porcherot for realisation of the manuscript.

Crystalline porcine glucagon and beef insulin were kindly given by Eli Lilly Research Laboratories (Indianapolis, USA) and Boots Ltd (Nottingham, England) respectively.

This study was supported by the CNRS (ERA 188), the INSERM (contrat $\mathrm{n}^{\circ}$ 75.1.051.4) and the "Fondation pour la recherche médicale française").

\section{References}

1. Assan, R., Rosselin, G., Dolais, J.: Effets sur la glucagonémie des perfusions et ingestions d'acides aminés. J. Ann. Diabetol. Hotel Dieu 7, 25-41 (1967)

2. Balasse, E. O., Ooms, H. A.: Role of plasma free fatty acids in the control of insulin secretion in man. Diabetologia 9, 145-151 (1973)

3. Desbals, P.: Effet de la pancréatectomie et de l'hypophysectomie sur la circulation des lipides chez le canard. Thesis, Université Paul Sabatier, Toulouse 1972

4. Fajans, S. S., Floyd, J. C., Knopf, R. F., Conn, J. W.: Effect of amino acids and proteins on insulin secretion in man. Recent Prog. Horm. Res. 23, 617-656 (1967)

5. Fajans, S. S., Floyd, J. C., Pek, S., Knopf, R. F., Jacobson, M.: Effect of protein meals on plasma insulin in mildly diabetic patients. Diabetes 18, 523-528 (1969)

6. Foltzer, Ch.: Antehypophyse, corticosurrénale et régulation de la sécrétion des hormones pancréatiques chez le canard. Thesis, Strasbourg 1977

7. Foltzer, Ch., Karmann, H.: Personal communication

8. Foltzer, Ch., Mialhe, P.: Pituitary and adrenal control of pancreatic endocrine function in the duck. II. Free fatty acids, amino acids, insulin and pancreatic glucagon variations following hypophysectomy and replacement therapy by growth hormone and corticosterone. Diabète Métab. 2, 101-105 (1976)

9. Gerich, J. E., Arthur Charles, M., Grodsky, G. M.: Characterization of the effects of arginine and glucose on glucagon and insulin release from the perfused rat pancreas. J. Clin. Invest. 54, 833-841 (1974)

10. Gerich, J.E., Langlois, M., Schneider, V., Karam, J.H., Noacco, C.: Effects of alterations of plasma free fatty acid levels on pancreatic glucagon secretion in man. $\mathbf{J}$. Clin. Invest. 53, 1284-1289 (1974)

11. Gerich, J. E., Lorenzi, M., Tsalikian, E., Bohannon, N. V., Schneider, V., Karam, J. H., Forsham, P. H.: Effects of acute insulin withdrawal and administration on plasma glucagon responses to intravenous arginine in insulin dependent diabetic subjects. Diabetes 25, 955-960 (1976)

12. Grande, F.: Lack of insulin effect on FFA mobilization produced by glucagon in birds. Proc. Soc. Exp. Biol. Med. 130, 711-713 (1969)

13. Gross, R., Mialhe, P.: Free fatty acid-glucagon feed-back mechanism. Diabetologia 10, 277-283 (1974)

14. Gross, R., Mialhe, P.: Roles of insulin and glucose in the regulation of plasma FFA in the duck. I. In the absence of pancreatic glucagon. Diabetologia 14, 185-190 (1978)

15. Heding, L. G., Frandsen, E. K., Jacobsen, H.: Structure-function relationship: Immunologic. Metabolism 25, 1327-1329 (1976)

16. Hoffman, W. S.: A rapid photoelectric method for the determination of glucose in blood and urine. J. Biol. Chem. 120, 51-55 (1937)

17. Karmann, H.: Personal communication

18. Krug, E., Mialhe, $P .:$ The contribution of the pancreas and the intestine to the regulation of lipolysis in birds. 2. Impaired lipolytic activity of pancreatic glucagon in the absence of either the pancreas or the intestine in the chicken. Horm. Metab. Res. 8, 345-350 (1975)

19. Krug, E.: Régulation de la lipolyse chez le canard: Importance des glucagons pancréatiques, de l'entéroglucagon et des facteurs intestinaux. Thesis, Université Louis Pasteur, Strasbourg 1976

20. Langslow, D. R., Hales, C. N.: Lipolysis in chicken adipose tissue in vitro. J. Endocrinol. 43, 285-294 (1969)

21. Laurell, S., Tibling, G.: Colorimetric microdetermination of free fatty acids in plasma. Clin. Chim. Acta 16, 57-62 (1967)

22. Laurent, F., Mialhe, P.: Insulin and the glucose-glucagon feedback mechanism in the duck. Diabetologia 12, 23-33 (1976)

23. Leclercq-Meyer, V., Mialhe, P., Malaisse, W. J.: Une méthode de dosage radioimmunologique du glucagon comportant une séparation par le charbon dextran. Diabetologia 6, 121-129 (1970)

24. Luyckx, A. S., Lefebvre, P. J.: Arguments for a regulation of pancreatic glucagon secretion by circulating plasma free fatty acids. Proc. Soc. Exp. Biol. Med. 133, 524-528 (1970)

25. Madison, L. L., Seyffert, W. A. Jr., Unger, R. H., Barker, B.: Effect of plasma free fatty acids on plasma glucagon and serum insulin concentrations. Metabolism 17, 301-304 (1968)

26. Marliss, E. B., Aoki, T.T., Cahill, G. F.: Glucagon and aminoacid metabolism. In: P. J. Lefebvre, R. H. Unger (Ed.): Glucagon. Molecular Physiology, (Clinical and Therapeutic Implications, pp. 123-150. Oxford: Pergamon Press 1972

27. Mialhe, P.: Glucagon, insuline et régulation endocrine de la glycémie chez le canard. Acta Endocrinol. [Suppl.] (Kbh) 36 (1958)

28. Mialhe, P.: Does an understanding of experimental diabetes advance the knowledge of spontaneous diabetes? (Studies on glucagon and its possible role in diabetes). In: R. R. Rodriguez (ed.): Proceedings VII Congress IDF, Buenos Aires, 1970 Int. Congr. Ser. 231, pp. 843-853. Amsterdam: Excerpta Medica 1971

29. Mialhe, P.: The role of glucagon in birds and mammals. In: T. A. I. Grillo, L. Liebson, A. Epple (Ed.): The evolution of pancreatic islets, pp. 291-300. Oxford: Pergamon Press 1976

30. Mialhe, P., Krug, E., Gross, R.: Hormonal control of lipolysis: comparative aspects. In: V. H. T. James (Ed.): Proceedings of the V International Congress of Endocrinology, Hamburg. Endocrinology, Vol. 2, pp. 548-553, Int. Congr. Ser. 403. Amsterdam: Excerpta Medica 1976

31. Müller, W. A., Faloona, G. R., Aguilar Parada, E., Unger, R. H.: Abnormal alpha cell function in diabetes. Response to carbohydrate and protein ingestion. N. Engl. J. Med. 283, 109-115 (1970) 
32. Müller, W. A., Faloona, G. R., Unger, R. H.: The influence of the antecedent diet upon glucagon and insulin secretion. $N$. Engl. J. Med. 285, 1450-1454 (1971)

33. Ohneda, A., Parada, E., Eisentraut, A.M., Unger, R. H.: Characterization of response of circulating glucagon to intraduodenal and intravenous administration of amino acids. J. Clin. Invest. 47, 2305-2322 (1968)

34. Pagliara, A.S., Stillings, S. N., Hover, B., Martin, D. M., Matschinsky, F. M.: Glucose modulation of amino acidinduced glucagon and insulin release in the isolated perfused rat pancreas. J. Clin. Invest. 54, 819-832 (1974)

35. Samsel, J. F., Ledig, M.: Effets de l'arginine et de l'alanine sur la sécrétion du glucagon pancréatique et de l'entéroglucagon. J. Physiol. (Paris) 72, 841-856 (1976)

36. Samols, E. J., Tyler, J. M., Marks, V., Mialhe, P.: The physiological rôle of glucagon in different species. In: R. R. Rodriguez (Ed.): Proceedings III International Congress of Endocrinology, Mexico. Progress in Endocrinology, pp. 636-655, Int. Congr. Ser. 231. Amsterdam: Excerpta Medica 1967
37. Unger, R. H.: Pancreatic alpha cell function in diabetes mellitus. In: P. J. Lefebvre, R. H. Unger (Ed.): Glucagon, Clinical and therapeutic implications, pp. 253-254. Oxford: Pergamon Press 1972

38. Unger, R. H., Ohneda, A., Aguilar Parada, E., Eisentraut, A.M.: The role of aminogenic glucagon secretion in blood glucose homeostatis. J. Clin. Invest. 48, 810-822 (1969)

39. Wise, J. K., Hendler, R., Felig, P.: Evaluation of alpha cell function by infusion of alanine in normal, diabetic and obese subjects. N. Engl. J. Med. 288, 487-490 (1973)

Received: January 3, 1978,

and in revised form: May 5, 1978

Dr. F. Laurent

Laboratoire de Physiologie Générale

21, rue René Descartes

F-67000 Strasbourg

France 